\title{
Article/Artigo
}

\section{A retrospective serologic survey of hantavirus infections in the county of Cássia dos Coqueiros, State of São Paulo, Brazil}

\author{
Inquérito sorológico retrospectivo das infecções por hantavirus no município de Cássia dos \\ Coqueiros, Estado de São Paulo, Brasil
}

\begin{abstract}
Soraya Jabur Badra ${ }^{1,2}$, Felipe Gonçalves Mota Maia ${ }^{2}$, Glauciane Garcia Figueiredo ${ }^{2}$, Gilberto Sabino dos Santos Junior ${ }^{2}$, Gelse Mazzoni Campos², Luiz Tadeu Moraes Figueiredo² and Afonso Dinis Costa Passos ${ }^{1}$
\end{abstract}

\section{ABSTRACT}

Introduction: In recent years, hantavirus infections producing severe diseases have obtained an increased attention from public health authorities from the countries of Eurasia to the Americas. Brazil has reported 1,300 cases of hantavirus cardiopulmonary syndrome (HCPS) from 1993 to 2010 , with about 80 of them occurring in the northeast of the State of São Paulo, with $48 \%$ fatality rate. Araraquara virus was the causative agent of HCPS in the region. Considering that hantaviruses causing human disease in the Americas were unknown until 1993, we have looked for hantavirus infections in the population of Cássia dos Coqueiros county, northeast of the State of São Paulo, Brazil, before this time. This county has about 2,800 inhabitants and an economy based on agriculture, including cultivation of Brachiaria decumbens grass. The grass seeds are an important rodent attraction, facilitating transmission of hantavirus to man. Four HCPS cases were reported so far in the county. Methods: In this study, 1,876 sera collected from 1987 to 1990 were tested for IgG to hantavirus by IgG-ELISA, using the $\mathrm{N}$ recombinant protein of Araraquara virus as antigen. Results: Positive results were observed in 89 (4.7\%) samples, which were all collected in 1987 . The positivity among urban inhabitants was $5.3 \%$, compared with $4.3 \%$ among those living in rural areas. Conclusions: Our results showed that hantavirus infections occurred in Cássia dos Coqueiros, completely unrecognized, even before hantaviruses were described in the Americas.

Keywords: Hantavirus. Serologic survey. Cássia dos Coqueiros.

\section{RESUMO}

Introdução: Infecções graves por hantavírus têm obtido crescente atenção das autoridades da saúde pública da Eurásia e Américas. De 1993 a 2010, o Brasil reportou 1.300 casos de síndrome pulmonar cardiovascular por hantavírus (SPCVH) com, aproximadamente, 80 deles no nordeste do Estado de São Paulo com taxa de fatalidade de $48 \%$. O vírus Araraquara é o agente etiológico da SPCVH nessa região. Considerando que nas Américas as doenças em humanos causadas por hantavírus eram desconhecidas até 1993, procuramos infecções por hantavírus nas populações do município de Cássia dos Coqueiros, nordeste de São Paulo, Brasil, antes dessa data. Esse município tem 2.800 habitantes e economia baseada na agricultura, com intenso cultivo da gramínea Brachiaria decumbens. Sementes de gramíneas têm um papel importante em atrair roedores, facilitando a transmissão de hantavírus para humanos. Nesse município, até o momento 4 casos haviam sido reportados. Métodos: Neste estudo, coletou-se 1.876 soros entre 1987 a 1990 e testamos para pesquisa de IgG contra hantavirus utilizando um ELISA que tem como antígeno a proteína $\mathrm{N}$ recombinante do vírus Araraquara. Resultados: Dentre os soros analisados, 89 (4,7\%) foram positivos, mostrando que esta infecção já ocorria previamente à descrição dos hantavirus americanos e deve estar ocorrendo há anos nesta região. A positividade entre os habitantes urbanos foi de 5,3\% se comparado com 4,3\% entre aqueles que viviam em áreas rurais. Conclusões: Nossos resultados mostraram que as infecções ocorridas por hantavirus foram completamente despercebidas em Cássia dos Coqueiros antes da descrição do hantavirus americano.

Palavras-chaves: Hantavírus. Inquérito sorológico. Cássia dos Coqueiros.

1.Departamento de Saúde Pública, Faculdade de Medicina de Ribeirão Preto, Universidade de São Paulo, Ribeirão Preto, SP. 2. Centro de Pesquisa em Virologia, Faculdade de Medicina de Ribeirão Preto, Universidade de São Paulo, São Paulo, SP.

Address to: Dra. Soraya Jabur Badra. Centro de Pesquisa em Virologia/FMRP/USP. Av. Bandeirantes 3900, Monte Alegre, 14049-900 Ribeirão Preto, SP, Brasil.

Phone: 55 16 3602-3376

e-mail: sorayajb@fmrp.usp.br

Received in 25/07/2011

Accepted in 10/01/2012

\section{INTRODUCTION}

Recognized in 1993, hantavirus cardiopulmonary syndrome (HCPS) is an emergent disease reported in many countries of the American continent. Until November 2010, Brazil has the highest number of HCPS patients in the Americas with about 1,300 reported cases ${ }^{1}$. It is a severe disease that produces pneumonia and shock, and its case fatality rate has reached 39\% in Brazil. Thus, HCPS being a recently identified disease, little is known about antibody levels to hantavirus in the general population, as well as how long infections caused by these viruses have occurred in the country. In this study, we present a serologic survey about hantavirus in sera collected from 1987 to 1990 at the county of Cássia dos Coqueiros, State of São Paulo, Brazil, which is located in an area where several cases of the disease have been observed recently.

\section{METHODS}

\section{Studied population}

Serum samples were collected from 1987 to 1990 from 1,876 urban and rural inhabitants of Cássia dos Coqueiros county, located in the northeast of the State of São Paulo, which is about $360 \mathrm{~km}$ away from São Paulo City, the state capital. In this region, about 80 HCPS cases were reported, mostly caused by Araraquara virus, which has Necromys lasiurus as rodent-reservoir ${ }^{2}$.

Participants were included in a populationbased survey carried out from 1987 to 1990 to study the distribution of hepatitis B markers. They corresponded to $67 \%$ of the total local population at the time and included both urban and rural inhabitants. The samples are currently part of a serum bank in the Laboratory of Serology of the General Hospital of The School of Medicine of Ribeirão Preto, University of São Paulo.

\section{Serologic test}

Sera were tested by an indirect IgG-enzymelinked immunoabsorbent assay (ELISA) using 
the $\mathrm{N}$ recombinant protein of Araraquara hantavirus as antigen ${ }^{3,4}$ Briefly, polystyrene microtiter plates (Nunc, Denmark) were coated overnight in a wet chamber at $4^{\circ} \mathrm{C}$ with $2 \mu \mathrm{g} / \mathrm{mL}$ of ARAV rN antigen and the respective control. All incubations were conducted at $37^{\circ} \mathrm{C}$ for $1 \mathrm{~h}$, and plates were washed six times with a wash buffer (phosphate-buffered saline [PBS]-0.1\% Tween 20) between each step. All reagents were added at volumes of $0.1 \mathrm{~mL}$. All serum samples were diluted at $1: 200$ in dilution buffer $(5 \%$ skim med milk powder in PBS-Tween 20), and double dilutions up to 1:6,400 were added to the antigen-coated wells. Peroxidase-labeled affinity-purified goat antihuman IgG Fc antibody was added, and a specific antibody binding was detected by the addition of 2,2'-azino-bis 3-ethylbenzthiazoline6-sulfonic acid (ABTS) substrate with absorbance measured at $405 \mathrm{~nm}$. Values were expressed as the optical density (OD) obtained with ARA rN antigen minus the OD values for the control antigens. The cut-off value of the test was determined by the mean plus 3 standard deviations of the ODs obtained for at least 4 negativecontrol serum samples plus 3 standard deviations of the mean.

\section{Data analysis}

Possible associations between positive results and some demographic and socioeconomic variables were studied using the Chi-square test, with a level of significance of $\mathrm{p}<0.05$.

\section{Ethical considerations}

The samples used for this study were authorized by the Ethics Committee of the same hospital (6998/2007), respecting the confidentiality of the information provided by and derived from the participants.

\section{RESULTS}

The 89 positive participants corresponded to a prevalence of $4.7 \%$ (CI95\%: $3.8 \%-5.7 \%$ ), with no difference between sex (Table 1). Similar distribution was observed among the different age ranges, varying from $3.4 \%$ to $5.2 \%(\mathrm{p}=0.950)$.

As seen in Table 2, the prevalence among urban inhabitants was 5.3\% (CI95\%: 3.7\%-6.9\%), compared with 4.3\% (CI95\%: 3.1-5.6) observed among those living in rural areas $(\mathrm{p}=0.336)$.

No associations were observed between the presence of antibodies to hantavirus and the variables scholarship, place of birth, and time of residence in Cássia dos Coqueiros.

TABLE 1 - Antibodies to hantavirus according to sex and age of the participants.

\begin{tabular}{|c|c|c|c|c|c|c|c|c|c|}
\hline \multirow[b]{3}{*}{ Age range } & \multicolumn{6}{|c|}{ Sex } & & & \\
\hline & \multicolumn{3}{|c|}{ Male } & \multicolumn{3}{|c|}{ Female } & \multicolumn{3}{|c|}{ Total } \\
\hline & pos & total & $\%$ & pos & total & $\%$ & pos & total & $\%$ \\
\hline $0-9$ & 8 & 163 & 4.9 & 2 & 130 & 1.5 & 10 & 293 & 3.4 \\
\hline $10-19$ & 10 & 205 & 4.9 & 12 & 235 & 5.1 & 22 & 440 & 5.0 \\
\hline $20-29$ & 11 & 170 & 6.5 & 7 & 182 & 3.8 & 18 & 352 & 5.1 \\
\hline $30-39$ & 3 & 126 & 2.4 & 11 & 146 & 7.5 & 14 & 272 & 5.1 \\
\hline $40-49$ & 5 & 109 & 4.6 & 6 & 101 & 5.9 & 11 & 210 & 5.2 \\
\hline $50-59$ & 6 & 68 & 8.8 & 0 & 76 & 0.0 & 6 & 144 & 4.2 \\
\hline$\geq 60$ & 2 & 93 & 2.2 & 6 & 72 & 8.3 & 8 & 165 & 4.8 \\
\hline Total & 45 & 934 & 4.8 & 44 & 942 & 4.7 & 89 & 1,876 & 4.7 \\
\hline
\end{tabular}

pos: positive samples.
TABLE 2 - Antibodies to hantavirus according to sex and area of residence.

\begin{tabular}{|c|c|c|c|c|c|c|c|c|c|}
\hline \multirow{3}{*}{$\begin{array}{l}\text { Area of } \\
\text { residence }\end{array}$} & \multicolumn{6}{|c|}{ Sex } & & & \\
\hline & \multicolumn{3}{|c|}{ Male } & \multicolumn{3}{|c|}{ Female } & \multicolumn{3}{|c|}{ Total } \\
\hline & pos & total & $\%$ & pos & total & $\%$ & pos & total & $\%$ \\
\hline Urban & 21 & 390 & 5.4 & 21 & 403 & 5.2 & 42 & 793 & 5.3 \\
\hline Rural & 24 & 544 & 4.4 & 23 & 539 & 4.3 & 47 & 1,083 & 4.3 \\
\hline Total & 45 & 934 & 4.8 & 44 & 942 & 4.7 & 89 & 1,876 & 4.7 \\
\hline
\end{tabular}

pos: positive samples.

\section{DISCUSSION}

In 1987, Cássia dos Coqueiros, State of São Paulo, was a small community with 2,871 inhabitants, having an economic activity based on agriculture and cattle raising that occupied $65 \%$ of the county area. At that time, there was an intensive farming of Brachiaria decumbens grass seeds in Cássia dos Coqueiros. This farming activity demanded hand labor and attracted hundreds of temporary migrants from the neighboring state of Minas Gerais, Brazil. A reliable generalization of the results to the whole community was assured by the fact that this was a population-based survey, which included almost $70 \%$ of the inhabitants, both urban and rural. Thus, $4.7 \%$ of the population of Cássia dos Coqueiros showed evidence of previous infection by hantavirus in the study period.

In 1999, another serologic survey to hantavirus, using IgGELISA, was carried out in three towns at the same region of Cássia dos Coqueiros, showing a $1.2 \%$ seropositivity ${ }^{5}$. In 2003, Campos et al. ${ }^{6}$ performed a serologic survey to hantavirus in Jardinópolis county, also in the same region, showing a $14.3 \%$ seropositivity. These different values could be attributed, in part, to the antigens used in the IgG-ELISA performed for the two surveys: a North American N protein antigen of Sin Nombre hantavirus N protein in 1999 and a South American Andes hantavirus N protein in 2003. The lower value found in the present investigation, when compared with the results of the Jardinópolis study, might have been caused by facts other than differences in the laboratory techniques, such as degradation of immunoglobulins in sera stored for more than 20 years. Likewise, it is impossible to completely disregard the circulation of distinct hantavirus in different towns of the region. Remarkably, a recent serologic survey in patients with acute febrile illness from Jardinópolis and Cássia dos Coqueiros, carried out with the same test used in this study (IgG-ELISA with the N recombinant protein of Araraquara hantavirus), showed prevalence values of $4.8 \%$ and $3.8 \%$, respectively ${ }^{7}$.

All sera for this serologic survey were collected from 1987 to 1990, and the finding of seropositivity demonstrated that hantavirus infections occurred in the region at least six years before its description as causing human diseases in the Americas. A retrospective study in North America also showed that HCPS occurred there since $1978^{8}$.

Before 1987, it was possible that cases of HCPS in Cássia dos Coqueiros were misdiagnosed as severe bacterial pneumonia or septicemia. Evidence of misdiagnosed HCPS was also seen in a study based on fatal cases of severe pneumonia that occurred in the decades of 1980 and 1990 in the City of Ribeirão Preto'. Unfortunately, we do not have any specific information on previous diseases suggestive of HCPS in the participants of this serologic survey. However, it is possible that most of the participants infected with hantavirus observed in this study did not present a severe disease but were oligosymptomatic or even asymptomatic. 
Similar rates of infection were observed among all age ranges, including children. The absence of a cumulative effect along the age groups was an unexpected finding for which we do not have a consistent explanation. Eventually, it might suggest that these infections occurred in the county in 1987. Indeed, it was corroborated by four HCPS cases detected in Cássia dos Coqueiros after 2000. Only a few serologic surveys reported antibody levels to hantavirus in Brazilian children. In $1997^{10}$, Mascarenhas-Batista looked for antibodies for Hantaan hantavirus in students from the City of Salvador, State of Bahia, and found the highest levels, $13.2 \%$, among children 10 to 11 years old.

The fact that rural inhabitants did not show differences in prevalence when compared with those living in the city was also an unexpected finding, although infection by hantavirus had been eventually reported among urban dwellers in the same region ${ }^{6,7}$. The most reasonable explanation for this finding involves some peculiar features of the studied population wherein it is really difficult to precisely separate urban and rural expositions. In fact, many urban inhabitants own small farms close to the city where they maintain agricultural activities, increasing the possibility of contact with wild rodents or their excreta. Additionally, even people living and working in urban areas have access in farms for recreation purposes, such as fishing during weekends. Unfortunately, we do not have any specific information on contact with rodents or previous diseases suggestive of HCPS, as the survey where blood collection originated was designed for getting information on risk factors for hepatitis B only.

Previous reports, before 1993, showed people from other Brazilian regions presenting antibodies to Asian hantavirus ${ }^{11,12}$. Nevertheless, this study is the first in Brazil to report infections by hantavirus causing HCPS at least 6 years before its recognition ${ }^{13}$.

\section{ACKNOWLEDGMENTS}

We acknowledge Mrs. Margarida Maria Passeri do Nascimento in aiding with the serum bank.

\section{FINANCIAL SUPPORT}

The Fundação de Amparo à Pesquisa do Estado de São Paulo (2008/50617-6) has supported the serologic tests.

\section{CONFLICT OF INTEREST}

The authors declare that there is no conflict of interest.

\section{REFERENCES}

1. Boletim Eletrônico Epidemiológico 2010, ano 10, n², SVS/MS. Disponível em http://portal.saude.gov.br/portal/arquivos/pdf/ano10_n02_sit_epidemiol_ zoonoses_br.pdf

2. Figueiredo LTM, Moreli ML, Sousa RLM, Borges AA, Figueiredo GG, Machado AM, et al. Hantavirus Pulmonary Syndrome, Central Plateau, Southeastern, and Southern Brazil. Emerg Infect Dis 2009; 15:561-567.

3. Moreli ML, Quintana HG, Figueiredo GG, Souza RLM, Figueiredo LTM. Expression of a Hantavirus $\mathrm{N}$ protein and its efficacy as antigen in immune assays. Braz J Med Biol Res 2008; 41:596-599.

4. Figueiredo LTM, Moreli ML, Borges AA, Figueiredo GG, Badra SJ, Bisordi I, et al. Evaluation of an Enzyme-Linked Immunosorbent Assay Based on Araraquara Virus Recombinant Nucleocapsid Protein. Am J Trop Med Hyg 2009; 81:273276

5. Holmes R, Boccanera R, Figueiredo LTM, Mancano SR, Pane C. Seroprevalence of human hantavirus infection in the Ribeirão Preto region of Sao Paulo State, Brazil. Emerg Infect Dis 2000; 6:560-561.

6. Campos GM, Sousa RLM, Badra SJ, Pane C, Gomes UA, Figueiredo LTM. Serological survey of hantavirus in Jardinópolis county, Brazil. J Med Virol 2003; 71:417-422

7. Figueiredo GG, Borges AA, Campos GM, Machado AM, Saggioro FP, Sabino-Santos Jr G, et al. Diagnosis of human and rodent infections by hantavirus in Ribeirão Preto, Brazil. Rev Soc Bras Med Trop 2010; 43:348-354.

8. Zaki SR, Greer PW, Coffield LM, Goldsmith CS, Nolte KB, Foucar K, et al. Retrospective Diagnosis of Hantavirus Pulmonary Syndrome,1978-1993. Arch Pathol Lab Med 1996; 120:134-139.

9. Rocha JSY, Figueiredo LTM. A procura de casos de hantaviroses. Estudo das hospitalizações na Região de Ribeirão Preto, SP. Abstracts. Salvador: Anais do VI Congresso Brasileiro de Saúde Coletiva; 2000.

10. Mascarenhas-Batista AV, Rosa ES, Ksiazek TG, Rosa AP, Leduc JW, Pinho F, et. al. Anticorpos Anti-Hantavírus em escolares de Salvador, Bahia. Rev Soc Bras Med Trop 1998; 31:433-440.

11. Hindrichsen S, Andrade AM, Clement J, Leirs H, McKenna P, Matthys P, et. al. Hantavirus infection in Brazilian patients from Recife with suspected leptospirosis. Lancet 1993; 341:50.

12. Iversson LB, Rosa AP, Rosa MD, Lomar AV, Sasaki MG, Leduc JW. Human infection by Hantavirus in southern and southeastern Brazil. Rev Assoc Med Bras 1994; 40:85-92.

13. Campos GM, Borges AA, Badra SJ, Figueiredo GG, Souza RLM, Moreli ML, et. al. Síndrome Pulmonar e Cardiovascular por Hantavírus: aspectos clínicos de uma doença emergente no sudeste brasileiro. Rev Soc Bras Med Trop 2009; 42:282-289. 